\title{
Yield and antioxidant activity of microgreens Petroselinumcrispum
}

\author{
(C) Valery N. Zelenkov, ${ }^{1,2,3}$ Maria I. Ivanova, ${ }^{1,2}$ \\ Vyacheslav V. Latushkin, ${ }^{3}$ and Anatoly A. Lapin ${ }^{4}{ }^{+}$ \\ ${ }^{1}$ All-Russian ScientificResearch Institute of Vegetable Growing Vegetables is a Branch of the Federal \\ Research Center for Vegetable Growing - the Branch of FSBSI "Federal Scientific Vegetable Center"500 \\ Vereya Village. Ramenskoe district. Moscow Region. Russia,140153.E-mail: ivanova_170@mail.ru \\ ${ }^{2}$ All-Russian Scientific Research Institute of Medicinal and Aromatic Plants. \\ Greene St., 7. Moscow, 117216. Russia.E-mail: zelenkov-raen@mail.ru \\ ${ }^{3}$ ANO Development Strategies Institute, St. Red Proletarian, 16, porch 5. \\ Moscow, 125319, Russia.E-mail: slavalat@yandex.ru \\ ${ }^{4}$ Department of Water Bioreservices and Aquaculture. Kazan Energy University. Krasnoselskaya St., 51. \\ Kazan, 420066. Republic of Tatarstan. Russia. Phone: +7 (843) 519-42-67. E-mail: lapinanatol@mail.ru
}

\begin{abstract}
*Supervising author; ${ }^{+}$Corresponding author Keywords: parsley, microgreens, antioxidant properties, seed germination, germination.
\end{abstract}

\begin{abstract}
The paper explores the germination of seeds, yields and an tioxidant properties of microgreens of different varieties and varieties of Petroselinumcrispum (Mill.) Nym. in controlled microclimatic conditions. The most active germination of seeds was observed in the interval of 7-11 days after sowing. The total increase in microgreens in height almost stops after 14 days of germination in the dark. Thus, growing products by germination in the dark is advisable longer than this period to get microgreens promising leafy varieties of parsley. A significant increase in total antioxidant activity in seed germination has been established - 2.7-5.6 times for different varieties. Parsley Petroselinumcrispum (Mill.) Nym. - a herbaceous plant used in many kitchens of the world as spicy and for the preparation of side dishes. The main flavor compounds of parsley are 1.3.8-n-metatrien, apiol, myristicin, and tetramethoxyallbenzene, of which apiol and mydisticin are "toxic in large doses". Green, herbaceous and fruit notes in parsley are determined by the hex3-enil, (Z)-hex-3-enol and (Z)-hex-3-enylacerate. It is proposed to use parsley as a component of functional products in the treatment of cancer. Growing parsley microgreens is advisable due to the high antioxidant and other beneficial properties. Despite the slow and time-stretched germination of seeds, within 2 weeks of cultivation formed a fairly high vegetative mass, which can be used for food and medicinal purposes, for example, as a product of functional nutrition. It is possible to grow products in the dark without the use of artificial light sources. The highest yield is provided by leafy varieties of parsley compared to root varieties.
\end{abstract}

\section{References}

[1] M.I. Ivanova. Celery and parsley (selection and primary seed production: theory, methodology, practice). Saarbrucken, Germany. 2012. 358p. (russian)

[2] B.E. Van Wyk. Culinary herbs and spices of the world (1st ed.). Chicago, IL. University of Chicago Press. 2014. 320p.

[3] C. Masanetz, W. Grosch. Key odorants of parsley leaves (Petroselinum crispum [Mill.] Nym. ssp. crispum) by odour-activity values. Flavour And Fragrance Journal. 1998. No.13(2). P.115-124. doi: 10.1002/(SICI)1099-1026(199803/04)13:23.0.CO;2-6.

[4] E. Tang, J. Rajarajeswaran, S. Fung, \& M. Kanthimathi. Petroselinum crispum has antioxidant properties, protects against DNA damage and inhibits proliferation and migration of cancer cells. Journal of the Science of Food and Agriculture. 2015. No.95(13). P.2763-2771. doi: 10.1002/jsfa. 7078

[5] A.W. Ebert, T.H. Wu, \& R.Y. Yang. Amaranth sprouts and microgreens e A homestead vegetable production option to enhance food and nutrition security in the rural-urban continuum. Families, farms, Food: Sustaining small scale vegetable production and marketing systems for food and nutrition securiy. Proceedings SEAVEG. Bangkog, Tailand. 2014. P.25-27.

[6] M.C. Kyriacou, Y. Rouphael, F. Di Gioia, A. Kyratzis, F. Serio, M. Renna, et al. Micro-scale vegetable production and the rise of microgreens. Trends Food Sci. Technol. 2016. Vol.57. P.103-115. doi: 10.1016/j.tifs.2016.09.005 
[7] M.C. Kyriacou, Y. Rouphael. Towards a new definition of quality for fresh fruits and vegetables. $\square S c i$. Hortic. 2018. No.234. P.463-469. doi: 10.1016/j.scienta.2017.09.046

[8] A. Drewnowski, \& C. Gomez-Carneros. Bitter taste, phytonutrients, and the consumer: A review. American Journal of Clinical Nutrition. 2000. Vol.72. P.1424-1435.

[9] E. Pinto, A.A. Almeida, A.A. Aguiar, I. Ferreira. Comparison between the mineral profile and nitrate oncentration of microgreens and mature lettuces. J Food Compos Anal. 2015. Vol.37. P.38-43. doi:10.1016/j.jfca.2014.06.018.

[10] Z. Xiao, G.E. Lester, Y. Luo, Q. Wang. Assessment of vitamin and carotenoid concentrations of emerging food products: edible microgreens. J. Agric. Food Chem. 2012. Vol.60. P.7644-7651.

[11] M.I. Ivanova, A.I. Kashleva, V.V. Mikhailov, O.A. Razin. Innovative specific products: organic sprouts (microgreens) and seedlings (babyleaves). Vegetables of Russia. 2016. No.1(30). P.29-33. (russian)

[12] C. Kaiser and M. Ernst. 2018. Microgreens. Center for Crop Diversification, University of Kentucky Collefe of Agriculture, Food and Environment. URL: http://www.uky.edu/ccd/sites/ www.uky.edu.ccd/ files/microgreens.pdf (reference date 30.10.2019)

[13] J.K. Craver, J.K. Boldt, and R.G. Lopez. Comparison of supplemental lighting provided by highpressure sodium lamps or light-emitting diodes for the propagation and finishing of bedding plants in a commercial greenhouse. Hort Science. 2019. Vol.54. P.52-59.

[14] C.F. Weber. Nutrient content of cabbage and lettuce microgreens grown on vermicompost and hydroponic growing pads. Journal of Horticulture. 2016. Vol.3. P.1-5.

[15] C. Sonneveld, W. Voogt. Plant Nutrition of Greenhouse Crops. Springer: Dordrecht, The Netherlands, 2009. Vol.15. 431p.

[16] GOST 12038-84. Seeds of crops. Methods for determining germination. Moscow: Publisher StandardInform. 1984. 65p. (russian)

[17] GOST 1936-85 Tea. Acceptance rules and analysis methods. Moscow: IPC Publishing Standards. 2001.10p. (russian)

[18] MX-50 humidity analyzer, zA. User handbook. Version 2.20 / February, 2003. A\&DCompany, Limited / External Trade Department. 31p. (russian)

[19] V.N. Zelenkov, A.A. Lapin. Total antioxidant activity. Measurement technique on a coulometric analyzer. MVI-01-00669068. Vereya, Moscow Region: All-Russian Research Institute of Vegetable Production. 2013. 19p. (russian)

[20] Fashion in statistics. URL: http://statanaliz.info/statistica/opisanie-dannyx/moda/ (reference date 30.10.2019). (russian)

[21] S.F. Oliveira, D.S. Costa, S.C. Mello, A.D.L.C. Novembre, F.G. Gomes-Junior. Germination of parsley eeds influenced by mericarps color and internal morphology. Horticultura Brasileira. 2013. Vol.31. P.231-235.

[22] W.G. Pill, E.A. Kilian. Germination and emergence of parsley in response to osmotic or matric seed priming and treatment with gibberellin. Hort Science. 2000. Vol.35. P.907-909.

[23] GOST 28676.1-90 - GOST 28676.14-90. Seeds of vegetable, melon crops and forage root vegetables. Variety and planting qualities. Specifications. Moscow: IPC Publishing Standards. 1991. 6p. (russian)

[24] G. Samuolienè, A. Brazaitytè, A. Virs` ilè, J. Jankauskienè, S. Sakalauskienė, P. Duchovskis. Red LightDose or Wavelength-Dependent Photoresponse of Antioxidants in Herb Microgreens. PLoS ONE. 2016. Vol.11. P.9-16.

[25] V.N. Zelenkov, V.V. Latushkin, M.I. Ivanova, A.A. Lapin, O.A. Razin, S.V. Gavrilov, P.A. Vernik. The influence of lighting on the seeds germination of chinese cabbage and broccoli and antioxidant activiti of microgreens in the closed system of synergotron ISR 1.01. Vegetables of Russia. 2019. No.6. P.146-150. Doi org/10/10.186 19/2072-9146-2019-6-146-150 